\title{
Was the Cold War a Security Dilemma?
}

\author{
$\because$ Robert Jervis
}

E xploring whether the Cold War was a security dilemma illuminates both history and theoretical concepts. The core argument of the security dilemma is that, in the absence of a supranational authority that can enforce binding agreements, many of the steps pursued by states to bolster their security have the effect-often unintended and unforeseen — of making other states less secure. The anarchic nature of the international system imposes constraints on states' behavior. Even if they can be certain that the current intentions of other states are benign, they can neither neglect the possibility that the others will become aggressive in the future nor credibly guarantee that they themselves will remain peaceful. But as each state seeks to be able to protect itself, it is likely to gain the ability to menace others. When confronted by this seeming threat, other states will react by acquiring arms and alliances of their own and will come to see the first state as hostile. In this way, the interaction between states generates strife rather than merely revealing or accentuating conflicts stemming from differences over goals. Although other motives such as greed, glory, and honor come into play, much of international politics is ultimately driven by fear. When the security dilemma is at work, international politics can be seen as tragic in the sense that states may desire-or at least be willing to settle for-mutual security, but their own behavior puts this very goal further from their reach. ${ }^{1}$

1. This perspective can be traced back to Thucydides; more modern variants are Herbert Butterfield, History and Human Relations (London: Collins, 1951), pp. 19-20; John Herz, "Idealist Internationalism and the Security Dilemma," World Politics, Vol. 2, No. 2 (January 1950), pp. 157-180; Arnold Wolfers, Discord and Collaboration (Baltimore: Johns Hopkins University Press, 1962), ch. 6; and Kenneth Waltz, Man, the State, and War (New York: Columbia University Press, 1959), ch. 6. My own treatments can be found in Perception and Misperception in International Politics (Princeton, NJ: Princeton University Press, 1976), ch. 3; and "Cooperation Under the Security Dilemma," World Politics, Vol. 30, No. 2 (January 1978), pp. 167-214. For analysis of the start of the Cold War, the rise and fall of détente, and the end of détente in terms of the security dilemma, see, respectively, Melvyn Leffler, A Preponderance of Power: National Security, the Truman Administration, and the Cold War (Stanford, CA: Stanford University Press, 1992); Raymond Garthoff, Détente and Confrontation: American-Soviet Relations from Nixon to Reagan, rev. ed. (Washington, DC: Brookings Institution,

Journal of Cold War Studies

Vol. 3, No. 1, Winter 2001, pp. 36-60

(C) 2001 by the President and Fellows of Harvard College and the Massachusetts Institute of Technology 
When faced with some kinds of security dilemmas_-but, as we shall see, not with others-states can take a number of steps to realize their common interests. They can seek to understand the compatibility of their objectives and can try to forge common ground by adopting a posture that is unambiguously defensive, increasing the incentives for cooperation, adopting safeguards against the risk that others will take advantage of them, and showing a willingness and ability to respond to both friendship and hostility. ${ }^{2}$ If a state exercises restraint, it may be able to induce others to reciprocate. But even if the security dilemma can be reduced by conciliation and reassurances, such policies will put the state in danger if the others turn out to be aggressive. Thus a central question is how the others will react (or, counterfactually, how they would have reacted) if the state behaves differently, especially by taking pacifying initiatives, making clear that it does not menace the others' legitimate interests, and seeking to maintain and even bolster the others' security. ${ }^{3}$

If the Cold War was a security dilemma, both sides should have been preoccupied with defending themselves. They also should have seen the strife as deeply regrettable and should have been searching for, or at least open to, ways of reducing tensions. They would have been inhibited in these efforts by concerns that the adversary would construe reasonableness as weakness. They would not have seized on opportunities to expand unless this was deemed vital to their own security, but they would have expected the other side to engage in such adventures. Thus, even if they were ready to reciprocate the other side's genuine concessions, they would likely have suspected that friendly gestures were meant to lull them into lowering their guard. ${ }^{4}$

Unfortunately, scrutiny of behavior alone is rarely sufficient to indicate

1994); and Alan Collins, The Security Dilemma and the End of the Cold War (New York: St. Martin's, 1997).

2. In addition to the above sources, see Kenneth Oye, Cooperation Under Anarchy (Princeton, NJ: Princeton University Press, 1986). More purely psychological studies include Charles Osgood, An Alternative to War or Surrender (Urbana: University of Illinois Press, 1962); Amitai Etzioni, The Hard Way to Peace (New York: Collier, 1962); and Herbert Kelman, ed., International Behavior: A Social-Psychological Analysis (New York: Holt, Rinehart, and Winston, 1965).

3. This counterfactual leads to the question of whether there were missed opportunities in the sense that better relations could have been established had one side been more conciliatory. See, for example, Deborah Welch Larson, Anatomy of Mistrust: U.S.-Soviet Relations During the Cold War (Ithaca: Cornell University Press, 1997). But a full-blown treatment of missed opportunities would also consider whether a tougher position would have yielded a better outcome See, for example, Vojtech Mastny, The Cold War and Soviet Insecurity: The Stalin Years (New York: Oxford University Press, 1996), pp. 164-70; and Zbigniew Brzezinski, "How the Cold War Was Played," Foreign Affairs, Vol. 51, No. 1 (October 1972), pp. 181-209.

4. For an imaginative attempt to use patterns of Soviet and American responses to each other's behavior in order to infer underlying intentions and the presence of a security dilemma, see William Gamson and Andre Modigliani, Untangling the Cold War (Boston: Little, Brown, 1971). In 1946 Maxim Litvinov privately told CBS correspondent Richard Hottelet that Western concessions would be met not by reciprocation, but by further demands; quoted in William Taubman, Stalin's American Policy: From Entente to Détente to Cold War (New York: Norton, 1982), p. 133. 
whether a security dilemma exists. The same hostile actions can flow from the hope for gain or the fear of loss, from offensive drives or defensive responses. Indeed if behavior alone could reveal the answer, states presumably would be able to recognize when they were in a security dilemma and would try to cope with it. We, as scholars, need to turn to the archives to determine whether a security dilemma existed during the Cold War. If it did exist, one or both sides should have been deeply fearful that the other side was aggressive or would become so in the future. Each side would have seen its own behavior as designed to maintain the status quo and would have welcomed measures to stabilize it. Although real disagreements and sources of conflict might have existed, the main obstacle to potential settlements of these issues would not have been the disagreements themselves, but the fear on each side of being exploited by the other side. If each side had been able to discern the other's motives (or archives), much of the conflict would have been avoided.

We should not, however, expect the evidence to yield an unambiguous conclusion: If we cannot decide whether World War I was the result of a security dilemma, it will hardly be surprising if we disagree about key aspects of the Cold War.

The diagnosis that the Cold War was a security dilemma would be politically and psychologically attractive. It is a "no fault" argument: No one was to blame and everyone was to blame. In this view, "gray is the color of truth," to quote McGeorge Bundy's claim about Vietnam. ${ }^{5}$ Decision makers may have been wrong, but given the ambiguous nature of the evidence available to them and the costs of incorrectly believing that the other side was not hostile, they were not ill-motivated or even unreasonable. ${ }^{6}$ This explanation can be politically useful both within and between countries. If the Cold War had wound down the way that Gorbachev hoped, rather than ending with the collapse of Communism and the Soviet Union, the security dilemma explanation would have provided a good basis for Soviet-American reconciliation.

5. Kai Bird, The Color of Truth: McGeorge Bundy and William Bundy, Brothers in Arms (New York: Simon \& Schuster, 1998).

6. The criterion of "reasonableness" is stressed by Leffler, $A$ Preponderance of Power. For a critique, see Robert Buzzanco, "What Happened to the New Left? Toward a Radical Reading of American Foreign Relations," Diplomatic History, Vol. 23, No. 4 (Fall 1999), pp. 581-583. For the contrasting argument that Leffler understates the Soviet threat and the American perception of Soviet strength, see Marc Trachtenberg, "Melvyn Leffler and the Origins of the Cold War," Orbis, Vol. 39, No 3 (Summer 1995), pp. 439-455. Whether subjective security requirements are reasonable or not is itself a subjective matter and is often hotly debated. Scholars strongly disagree about how to judge the reasonableness American and Soviet security demands. Looking back at the past fifty years of historiography, we can see changes in scholarly views of the unreasonableness of French security requirements after World War I. When it is believed that demands for security are unreasonable, a further debate ensues as to whether the demands were sincere but misguided or largely rationalizations for other objectives, most obviously expansionism. 


\section{Subtleties and Ambiguities in the Concept of the Security Dilemma}

In the security dilemma, both sides prefer the status quo to the costs and risks of seeking to expand. But things rarely are so simple. To start with, there are ambiguities in the basic concept of security, including what the object of security is (e.g., individuals, the regime, the state, or the values that any of these hold dear) and what is needed to make states or individuals feel secure. ${ }^{7}$ Even more troubling, the terms we commonly use to characterize states and the sources of their conduct-“aggressive," "expansionistic," "opportunitydriven," "risk-acceptant," "status quo," "security-seeking," "risk-averse"-are problematic, just as the definition of self-defense as a justification for murder is contentious. ${ }^{8}$ Few states are completely satisfied with the status quo; almost all will seek to improve their position (which ordinarily means harming others) from time to time if the costs and risks of doing so are minimal. But this is rarely possible, and some states will menace others only if such behavior is believed necessary for self-protection. A few, however, regard the status quo as unacceptable and are willing to pay a high price to change it. Although we often say that security is the foundation on which efforts to achieve any further goal must be mounted, states like Nazi Germany were willing to risk their own survival to gain a chance to shape the world according to their values.' Aggressive behavior should thus be regarded as entailing not only a desire to expand, but a willingness to undertake strenuous and dangerous efforts to do so, a willingness that is likely to be inversely proportional to the state's satisfaction with the status quo. Some states are relatively satiated and content with the prevailing situation, whereas others are very dissatisfied and strongly motivated to change it. Even if contemporary observers and later scholars often have difficulty in saying which state fits into which category, it gives us a usable, if rough, distinction.

This does not solve the entire problem, however. It is not always clear to decision makers which actions are safe and which are dangerous and costly. This limitation complicates the task not only of scholars who seek to explain state behavior, but also of the decision makers themselves, who need to predict how others will behave in the future. Thus while contemporary Western

7. The classic statement is Arnold Wolfers, "National Security as an Ambiguous Symbol," in Wolfers, Discord and Collaboration, ch. 10.

8. For related distinctions, see Randall Schweller, Deadly Imbalances: Tripolarity and Hitler's Strategy of World Conquest (New York: Columbia University Press, 1998), pp. 83-91.

9. This case and the destructive nature of modern warfare have given aggression a bad name and lead most of us, at least in the West, to accord status quo powers moral superiority. This is not warranted, as E. H. Carr pointed out in the revised edition of The Twenty Years' Crisis, 1919-1939 (New York: Harper \& Row, 1964). 
leaders and many later scholars construed the North Korean attack on South Korea in 1950 as evidence that Josif Stalin was willing to run high risks in order to expand the Communist domain, it now seems clear that he authorized the invasion only because he was convinced that the United States would not resist. $^{10}$

A more fundamental difficulty arises when security is equated with the preservation of the status quo. At certain junctures so many forces for change are at work that the situation cannot be maintained at an acceptable price. This makes it hard to build the concept of the security dilemma around selfdefeating efforts to keep states secure in their existing positions. A related complication is that even if mutual security is acceptable, it may not be attainable. If each side can feel secure only when it has a larger army than the other, an abstract agreement on a willingness to forgo advantages so that both sides can gain security will be illusory. More broadly, if leaders share the view of the minister to Catherine the Great who claimed that a defensive position condemns a state to decline because "that which stops growing begins to rot," then security and maintenance of the status quo will be incompatible, and states will be forced to compete even if their primary goal is security. ${ }^{11}$

We thus cannot universally contrast expansionism with security-seeking. The former may in fact be pursued as a route to the latter. A state may be insecure, but this insecurity cannot be alleviated even if potential adversaries take reasonable and reassuring actions. An attempt to conciliate such a state would be as fruitless and dangerous as trying to appease an aggressor. The fact that the state's motives are actually defensive does not matter. Thus Henry Kissinger has argued that revolutionary regimes are disruptive not so much because they are inherently aggressive, but because their fundamental insecurity prevents them from being reassured. ${ }^{12}$ In the most extreme case, a state

10. The classic article on the contemporary American perceptions is Alexander George, "American Policy-Making and the North Korean Aggression," World Politics, Vol. 7, No. 2 (January 1955), pp. 209-32. The latest evidence on Soviet expectations is presented in Kathryn Weathersby, "Korea, 1949-50: To Attack, or Not to Attack? Stalin, Kim Il Sung, and the Prelude to War," Cold War International History Project Bulletion, No. 5 (Spring 1995), pp. 1-9; and Kathryn Weathersby, "New Russian Documents on the Korean War," in ibid., No. 6-7 (Winter 1995/1996), pp. 30-40. For a discussion of the flaws in Stalin's and Vyacheslav Molotov's understanding of what actions were risky, see Vladislav Zubok and Constantine Pleshakov, Inside the Kremlin's Cold War: From Stalin to Khrushchev (Cambridge, MA: Harvard University Press, 1996), pp. 52-53, 70, 94.

11. Quoted in Adam Ulam, Expansion and Coexistence: The History of Soviet Foreign Policy, 1817-67 (New York: Praeger, 1968), p. 5. In 1920 the U.S. Navy's General Board similarly declared: "A nation must advance or retrocede in world position." Quoted in William Braisted, The United States Navy in the Pacific, 1909-1922 (Austin: University of Texas Press, 1971), p. 488. Many Germans believed that the choice facing their country before World War I was between "world power or decline." Fritz Fischer, World Power or Decline, trans. by Lancelot Farrar, Robert Kimber, and Rita Kimber (New York: Norton, 1974).

12. Henry Kissinger, $A$ World Restored (New York: Grosset \& Dunlap, 1964), p. 2. For a more thorough discussion, see Stephen Walt, Revolution and War (Ithaca, NY: Cornell University Press, 1996). 
might be menaced by the mere existence of others. In what can be called a "deep" security dilemma, both sides may be willing to give up the chance of expansion if they can be made secure, but a number of other factors- the fear that the other's relative power is dangerously increasing, technology, events outside their control, and their subjective security requirements- put such a solution out of reach. In one version of this explanation, the Cold War was a clash between different social systems, and the one thing on which the two sides agreed was that the world could not last indefinitely "half slave and half free." In such a deep security dilemma, unlike one based on mistrust that could be overcome, there are no missed opportunities for radically improving relations.

A related complication is that whether a situation is a security dilemmaand whether offensive or defensive motives are at work-depends in part on which segment of the means-ends chain one examines. At first glance, the $\mathrm{Cu}$ ban missile crisis appears to have been a security dilemma, produced by a combination of U.S. misperceptions of the pace of the Soviet missile program (exacerbated by domestic politics) and exaggerated Soviet concerns about the security of both Cuba and the USSR. Each side merely wanted to keep the other in check, and the crisis ended when each understood this. But recent scholarship indicates that Nikita Khrushchev wanted missiles in Cuba and greater security against a U.S. first strike in order to put pressure on U.S. positions in West Berlin. ${ }^{13}$ This makes his motives offensive and the security dilemma irrelevant. If, however, we ask why Khrushchev was so concerned about West Berlin, defensive motives and the security dilemma reappear. It is unlikely that he expected to push the United States out of West Germany, let alone out of Western Europe, although such a result would have pleased him. Rather, what he sought was to keep West Germany non-nuclear, to minimize American subversion of Eastern Europe, and to shore up the East German regime-objectives that did not deeply infringe on U.S. vital interests and were largely met in the Quadripartite Agreements and Helsinki Accords in the 1970s. In this analysis, the most important goals of the two sides were compatible. Not only the missile crisis, but also the conflict over West Berlin could have been avoided by greater understanding and statesmanship. ${ }^{14}$

13. Aleksandr Fursenko and Timothy Naftali, "One Hell of a Gamble": Khrushchev, Castro, and Kennedy, 1958-1964 (New York: Norton, 1997); and Ernest May and Philip Zelikow, The Kennedy Tapes: Inside the White House During the Cuban Missile Crisis (Cambridge, MA: Harvard University Press, 1997), pp. 666-680. For a rebuttal, see Barton Bernstein, "Understanding Decisionmaking, U.S. Foreign Policy, and the Cuban Missile Crisis: A Review Essay," International Security, Vol. 25, No. 1 (Summer 2000), pp. 150-151.

14. Dobrynin argues that in 1961 "Moscow . . . overlooked a very important point: President Kennedy's readiness to reach an understanding on the status quo in Europe." Anatoly Dobrynin, In Confidence: Moscow's Ambassador to America's Six Cold War Presidents (New York: Times Books, 1995), 
Several of these ambiguities are exemplified by Khrushchev's secret denunciation of the Soviet policies that triggered the Cold War: "It was literally a stupidity.... With our short-sighted policies we drove Turkey and Iran into the embraces of the U.S.A. and England." ${ }^{15}$ In this reading, which is almost certainly correct, Soviet policy itself decreased rather than increased Soviet security. But neither here nor elsewhere does Khrushchev come to grips with crucial questions: whether the Soviet Union would or should have been willing to settle for less; whether the pressure on neighbors was to be condemned only because it was so heavy handed; whether a sphere of influence along the USSR's southern border was necessary for Soviet security but could have been established by alternative means; and whether expanded influence was sought for extraneous reasons but should not have been. Different answers would have very different implications for Soviet motives and the changes that would have been needed to avoid the Cold War.

\section{Alternatives 16}

The most obvious alternative to a security dilemma explanation of the Cold War is the claim that one of the superpowers sought to expand in order to achieve nonsecurity goals. For example, the "traditionalist" or "orthodox" school of Cold War historiography sees an ideologically driven Soviet Union as inherently expansionistic. In this view, the United States was willing to accept reasonable settlements of key issues such as Germany, conduct in the Third World, and arms control, but the Soviet Union was not. Attempts at greater conciliation would have been useless and might even have invited Soviet pressure.

The second alternative is the "revisionist" view, which basically recapitulates the previous description, but transposes the roles of the two superpowers. The revisionists depict both American ideology and the needs of the domestic economic system as crucial. Although different authors describe the balance

p. 66. It remains unclear why Nikita Khrushchev refused to accept a settlement once Kennedy made clear that he would block West Germany's path to nuclear weapons. Marc Trachtenberg, A Constructed Peace: The Making of the European Settlement, 1945-1963 (Princeton, NJ: Princeton University Press, 1999).

15. Minutes of the 28 June 1957 meeting of the Central Committee Plenum, Cold War International History Project Bulletin, No. 10, (March 1998) p. 59. Also see Molotov's recollections in Albert Resis, ed., Molotov Remembers: Inside Kremlin Politics, Conversations with Felix Chuev (Chicago: Ivan R. Dee, 1993), pp. 73-74.

16. Some of these alternatives are incompatible with the security dilemma and with each other, but it is possible that the Cold War was overdetermined in the sense that several factors were present, any one of which would have been sufficient to produce intense hostility even in the absence of the others. 
and interaction between the two sides somewhat differently, they broadly agree that the Soviet Union had no opportunity to establish good relations with the United States other than by conceding U.S. dominance. This, they argue, was shown by the way the Cold War ended, when the United States refused to reciprocate Mikhail Gorbachev's concessions and instead demanded more and more until first the Soviet bloc and then the Soviet Union itself dissolved. If we compare this with American hostility toward the British Empire during World War II or with U.S. foreign policy in the post-Cold War era, we can see that even if the Soviet Union had never existed, the United States would have sought to thwart any potential rivals and open the world to American capitalist penetration. ${ }^{17}$

Parenthetically, I should note a third view that combines the first two but is espoused by very few people. This view depicts both sides as having sought to alter the status quo. Such a configuration is not precluded by logic; indeed, we analyze much of seventeenth- and eighteenth-century history in these terms, and this perspective is consistent with classical views of human nature, which regard humans as harboring original sin or its secular equivalent and being driven by the will to dominate. The reasons that this position is rarely defended, at least in the United States, are political and psychological. ${ }^{18}$ It is uncomfortable to find that no actors on the world scene are sympathetic. In a polarized atmosphere, such a view would be likely to result in a portrayal of both superpowers as aggressive or evil. This largely explains why so many revisionists fell into the trap of seeing Soviet foreign policy as relatively benign when their intellectual apparatus and the bulk of the available evidence dealt solely with American motives and behavior. The other side of this coin is that, contrary to casual impressions, disclosures from the Soviet archives cannot refute the revisionists' claims about the United States.

A fourth alternative, not entirely inconsistent with any of the above, argues that the superpowers were driven more by internal forces than by the external environment. Rather than being a form of interaction, the Cold War in this view resulted from independent national policies. ${ }^{19}$ Although the nature

17. See, for example, Walter LaFeber, "The Tension Between Democracy and Capitalism during the American Century,” Diplomatic History, Vol. 23, No. 23 (Spring 1999), pp. 263-284; and Walter LaFeber, "Rethinking the Cold War and After: From Containment to Enlargement," in Allen Hunter, ed., Rethinking the Cold War (Philadelphia: Temple University Press, 1998), pp. 35-46.

18. European scholars come closest to seeing both the United States and the Soviet Union as culpable and often reprehensible. Because they depict their own countries as blameless, is easier for them to find the Olympian heights from which to castigate both superpowers.

19. Thus while Garthoff's Détente and Confrontation analyzes this period in terms of interaction, his account of the end of the Cold War, The Great Transition: American-Soviet Relations and the End of the Cold War (Washington, DC: Brookings Institution, 1994), locates the causes almost entirely within 
of domestic politics was different on each side, its primacy was not. Thus, John Gaddis's study of American policies at the start of the Cold War stresses the conflicts between the political parties and among the branches of government. Similarly, Robert Slusser and Harry Gelman have explained Soviet policy as the byproduct of power struggles within the Politburo. ${ }^{20}$ In this perspective, the insecurity of leaders and factions rather than that of the country as a whole is the most important cause of international behavior. Such a view implies that it would have been difficult for either side to have behaved in a way that would have elicited desired responses from the other. A related argument sees domestic politics and public opinion in the United States as a cause of the Cold War not only because of the public's susceptibility to fear and antiCommunism, but also because of its idealism and impatience with compromise. Proponents of this view contend that when Harry Truman wanted to convince the public that the Soviet Union could no longer be treated as an ally, he had to exaggerate the Soviet threat. Once the public was aroused, the argument goes, leaders knew they would suffer if they attempted to reduce tensions. This same dynamic implies that Richard Nixon and Henry Kissinger were able to sell détente only by exaggerating its benefits, thereby planting the seeds for the rejection of their approach when it failed to live up to the public's unrealistic expectations.

A final explanation, which can be seen as an alternative to the security dilemma or as a form of it, dismisses the role of internal factors and instead stresses the importance of bipolarity. The superpowers were "enemies by position," to use a phrase of Raymond Aron's. Because each was the only state powerful enough to rival the other, their relations inevitably would be characterized by fear and hostility. ${ }^{21}$ The problem with this view, however, is that bi-

the USSR, with American actions playing only a small role, either for good or-mostly—for bad. For a critique on these grounds, see Richard Pipes, "Misinterpreting the Cold War: The Hard-Liners Had It Right," Foreign Affairs, Vol. 74, No. 1 (January/February 1995), pp. 154-160; and the exchange between Garthoff and Pipes, ibid., Vol. 74, No. 3 (May/June 1995), pp. 197-200.

20. John Gaddis, The United States and the Origins of the Cold War, 1941-1947 (New York: Columbia University Press, 1972); Robert Slusser, The Berlin Crisis of 1961: Soviet-American Relations and the Struggle for Power in the Kremlin (Baltimore: Johns Hopkins University Press, 1973); and Harry Gelman, The Brezhnev Politburo and the Decline of Détente (Ithaca, NY: Cornell University Press, 1984). Also see Jack Snyder, Myths of Empire: Domestic Politics and International Ambition (Ithaca: Cornell University Press, 1991), ch. 6; László Borhi, "Rollback, Liberation, Containment, or Inaction? U.S. Policy and Eastern Europe in the 1950s," Journal of Cold War Studies, Vol. 1, No. 3 (Fall 1999), pp. 67-110; and Patrick Morgan and Keith Nelson, eds., Re-Viewing the Cold War: Domestic Factors in the East-West Confrontation (Westport, CT: Praeger, 2000). This approach is also employed in Richard Neustadt, Alliance Politics (New York: Columbia University Press, 1970).

21. The most important analysis of bipolarity is Kenneth N. Waltz, Theory of International Politics (Reading, MA: Addison-Wesley, 1979). The debates over bipolarity centered on the stability of the system, with little attention to the less pressing question of how much the superpowers could cooperate. For discussion of whether bipolarity mandates conflict between the superpowers throughout the world, see Robert Jervis, System Effects: Complexity in Political and Social Life (Princeton, NJ: Princeton 
polarity was in part the product of the Soviet and American decisions to mobilize national resources and rally allies_-decisions that followed rather than preceded their hostility.

\section{Cooperation with Stalin?}

Several lines of argument converge on the conclusion that Josif Stalin's outlook and behavior provide a sufficient, though perhaps not a necessary, explanation of the onset of the Cold War. Even if Stalin was not willing to run significant risks in order to increase the Soviet Union's sphere of influence, his behavior was alarming. The strong revisionist claim that the fears voiced by American leaders regarding the Soviet Union were either manufactured or rationalizations for U.S. expansionism implies that Canadian and West European leaders viewed Soviet behavior more benignly, which does not appear to be the case.

More centrally, many Western fears seem reasonable in retrospect. Although Stalin's behavior was not always consistent, he was quite willing to take advantage of opportunities to expand in northern Iran, Turkey, and Korea. ${ }^{22}$ It can be argued that in the case of Iran, the Soviet Union sought only to control the oil fields, an objective shared by the Western powers. It can also be argued that the pressure on Turkey was motivated by a combination of standard security concerns and a desire to restore the old Tsarist borders. ${ }^{23}$ But

University Press, 1997), pp. 118-122. At the start of the Cold War, however, neither American nor Soviet leaders regarded the world as bipolar. American policy was premised on the belief that West European power was crucial for the struggle against the USSR, and Stalin thought that conflict among the capitalist states was inevitable and tried to take advantage of what he perceived to be a fierce rivalry between the United States and Great Britain. For the latter, see Fraser Harbutt, The Iron Curtain: Churchill, America, and the Origins of the Cold War (New York: Oxford University Press, 1986); and Vladimir Pechatnov, "The Big Three After World War II," Working Paper No. 13, Cold War International History Project, Washington, DC, July 1995.

22. Zubok and Pleshakov, Inside the Kremlin's Cold War, pp. 46-50; Odd Arne Westad, Cold War and Revolution: Soviet-American Rivalry and the Origins of the Chinese Civil War, 1944-1946 (New York: Columbia University Press, 1993); and Norman M. Naimark, The Russians in Germany: The History of the Soviet Zone of Occupation, 1945-1949 (Cambridge, MA: Harvard University Press, 1995). For the argument that Truman also was less consistent than he is usually portrayed, see Deborah Welch Larson, Origins of Containment: A Psychological Explanation (Princeton, NJ: Princeton University Press, 1985). Inconsistency poses a real problem for explaining behavior, especially for political scientists who seek parsimonious accounts. See Robert Jervis, "International History and International Politics: Why Are They Studied Differently?" in Colin Elman and Miriam Fendius Elman, eds., Bridges and Boundaries: Historians, Political Scientists, and the Study of International Relations (Cambridge, MA: MIT Press, 2000), pp. 385-402.

23. For Stalin's dissatisfaction with the USSR's southern borders, see Zubok and Pleshakov, Inside the Kremlin's Cold War, p. 17. For the pressure on Turkey, see Eduard Mark, "The War Scare of 1946 and its Consequences," Diplomatic History, Vol. 21, No. 3 (Summer 1997), pp. 383-416; Bruce Kuniholm, The Origins of the Cold War in the Near East: Great Power Conflict and Diplomacy in Iran, Turkey, and Greece (Princeton, NJ: Princeton University Press, 1980); and Leffler, Preponderance of 
if either or both of these probes had succeeded, further Soviet gains would have been likely, a consideration that Stalin could hardly have missed. His authorization of North Korea's attack on South Korea is even harder to explain in security terms. To be sure, there were opportunities Stalin did not seize, most obviously in Greece. These "dogs that do not bark" are often overlooked by analysts less acute than Sherlock Holmes, and it is hard to count them, much less give them their due. But this failing is shared by decision makers, which means that we should not expect scattered examples of restraint to obviate the more general perception of threat. In Stalin's case, moreover, the restraint was practiced mainly when there was an expectation of a strong Western response.

Even if Stalin sought security as a primary goal, it is hard to see what could have made him secure short of a complete retraction of American power from Western Europe and the Finlandization of much of the continent. Personality and ideology reinforced each other in making Stalin hard to reassure. Throughout his life he lacked true colleagues and saw rivals as mortal threats whom he had to eliminate not only figuratively but literally. ${ }^{24}$ This predisposition fit with the Communist view of capitalist states as inevitably hostile. Vladimir Pechatnov summarizes Stalin's basic attitude as revealed by the newly declassified correspondence between Stalin and Molotov in the fall of 1945: "The Anglo-Saxons are hostile, duplicitous, and anti-Soviet at heart, they understand only the language of firmness and strength. At worst they are hidden enemies, at best rivals." ${ }^{25}$ Although Stalin believed that specific, hardfought agreements were possible, he ruled out good relations between the two sides and saw no point to greater restraint than was required by the strength of the Western opposition. This suggests that it would have been extremely difficult to elicit cooperation from Stalin. ${ }^{26}$ Although the United States could have done more to assuage Soviet fears of the U.S. nuclear monopoly, it is hard to imagine any reasonable efforts that would have convinced the USSR to forgo nuclear weapons. How could Stalin of all people feel secure in a

Power, pp. 123-125, 142-144. For evidence of Stalin's general optimism and expansionism, see his speech to the Soviet Politburo on 14 March 1948, translated in Brian Murray, "Stalin, the Cold War, and the Division of China: A Multi-Archival Mystery," Working Paper No. 12, Cold War International History Project, Washington, DC, June 1995, pp. 18-22.

24. Robert C. Tucker, Stalin as Revolutionary, 1879-1929 (New York: Norton, 1973); Robert C. Tucker, Stalin in Power: The Revolution from Above (New York: Norton, 1990); and Zubok and Pleshakov, Inside the Kremlin's Cold War, chs. 1-2.

25. Vladimir Pechatnov, "The Allies are Pressing You to Break Your Will . . .' Foreign Policy Correspondence between Stalin and Molotov and Other Politburo Members, September 1945-December 1946," Working Paper No. 26, Cold War International History Project, Washington, DC, September 1999 , p. 8.

26. Taubman, Stalin's American Policy. 
world in which the capitalists, but not the Communists, knew how to build nuclear bombs?

Stalin's style and his knowledge of Soviet weakness led him to adopt tactics that were likely to increase Western fear and hostility. He told Molotov:

It is obvious that in dealing with such partners as the U.S. and Britain we cannot achieve anything serious if we begin to give in to intimidation or betray uncertainty. To get anything from this kind of partner, we must arm ourselves with the policy of tenacity and steadfastness. ${ }^{27}$

It is not clear whether Stalin gave much thought to the possibility that this approach might stiffen Western resolve by spurring U.S. leaders to exaggerate Soviet strength and unreasonableness. Even if he did, it is doubtful that he would have seen any other policy as viable. It is possible that if Stalin had provided a more complete and open explanation of Soviet fears, perceptions, and objectives, he would have evoked a more cooperative Western response, but such a stance was out of the question for the Soviet leader.

Indeed, a benign international environment was incompatible with Stalin's primary objective of maintaining repression and absolute power at home. Foreign enemies were necessary to justify his own role as supreme leader and the Communist Party's control of all spheres of life. Stalin also realized that contact with Westerners and knowledge of life in the West would undermine people's faith in Communism, as indeed proved to be the case, most strikingly among the elites in the 1980s. These prohibitions would have been harder to maintain if tensions were reduced.

Stalin's successors saw greater prospects for continued peace, especially because of their growing nuclear arsenal. They were less hopeful about the spread of Communism in Western Europe after it became clear that capitalism was not about to collapse. But they were not willing to forgo opportunities for expansion elsewhere. And why should they have been? The status quo was unacceptable to them not only because the West had enormous advantages, but also because Communist ideology instilled confidence that change was inevitable and that the Soviet Union had an "internationalist" duty to promote it. Thus, "Khrushchev longed for a more manageable and stable world, but in the name of revolution" and had no hesitation about pressing

27. Quoted in ibid., p. 14. The impact of Stalin's sense of weakness is stressed by Eric Hobsbawm, Age of Extremes: The Short Twentieth Century, 1914-1991 (London: Abacus, 1995), pp. 233-234. For a similar explanation of the periods of Chinese bellicosity, see Allen Whiting, The Chinese Calculus of Deterrence: India and Indochina (Ann Arbor: University of Michigan Press, 1975); and Melvin Gurtov and Byong-Moo Hwang, China Under Threat: The Politics of Strategy and Diplomacy (Baltimore: Johns Hopkins University Press, 1980). 
Kennedy hard when he thought that the new president was inexperienced and weak. ${ }^{28}$

It is also telling that the Soviet Union was never able to sustain good relations with any country outside its control, with the possible exceptions of Cuba and India. Of course the United States tried to disrupt Moscow's efforts to establish good relations, but the bulk of the responsibility surely must lie with Soviet leaders' own behavior and attitudes. This sorry record indicates how unlikely it was that even a more conciliatory United States would have been able to live in harmony with the Soviet Union after World War II.

\section{Stability, the Status Quo, and Soviet Ideology}

John Gaddis points out that states and people other than the superpowers helped determine the course of the Cold War. ${ }^{29}$ There is, however, another face to the diffusion of power: If change took place only at the instigation of the United States or the Soviet Union, the two sides might have kept arms and tensions to a lower level. But autonomous change, and the possibility of such change, were constant. At the start of the Cold War, U.S. officials regarded the Soviet Union as a major threat mainly because of the instability in Europe. Fluctuations in the perception of threat were at least as much a function of changing conditions within Western Europe as of shifts in Soviet power and behavior. ${ }^{30}$ Until the outbreak of the Korean War, there was no real fear of a Soviet military invasion of Western Europe. Rather, the worry was that the Soviet Union and its East European allies would take advantage of the devastated economies and social systems in the West, that the antiCommunist forces would lose heart, and that the Communists would gain power through a combination of elections, subversion, and unrest.

A decade later, these fears had shifted to the Third World, where radical change was welcomed and encouraged by Soviet leaders, who were confident that time was on their side. The conflicting perspectives and the underlying weakness of the American position were revealed by the dialogue between Kennedy and Khrushchev at Vienna in May 1961, which is telling enough to merit quotation at length:

28. Zubok and Pleshakov, Inside the Kremlin's Cold War, p. 182 (also see pp. 186, 260); and Dobrynin, In Confidence, pp. 43-45. For the argument that Khrushchev's odd combination of seeking revolutions and good relations with the United States is to be explained by his need to maintain a supporting coalition rather than his personal beliefs, see Snyder, Myths of Empire, pp. 246-250.

29. John Lewis Gaddis, We Now Know: Rethinking Cold War History (New York: Oxford University Press, 1997). Gaddis looks to the Europeans, who favored the United States. As a large number of critics have noted, the choices elsewhere were different.

30. Leffler brings this out well in Preponderance of Power, chs. 2-5. 
Mr. Khrushchev said that the West and the U.S. as its leader must recognize one fact: Communism exists and has won its right to develop.... His own interpretation of the situation was, the President [said], that the Soviet Union was seeking to eliminate free systems in areas that are associated with us. So while objecting to efforts directed at eliminating Communism in areas under the Communist system, Mr. Khrushchev appears to believe that it is appropriate to exert efforts to eliminate free systems. This is a matter of very serious concern to us.

Mr. Khrushchev said that this was an incorrect interpretation of Soviet policy. The Soviet Union is against implanting its policy in other states. As a matter of fact, this would be an impossible task. What the Soviet Union says is that Communism will triumph. This is a different proposition because it represents a teaching, a scientific analysis of social development. The United States may not accept this teaching, but the Soviet Union proceeds from one assumption alone, namely, that any change in the social system should depend on the will of the peoples themselves. The Soviet Union is for change. It believes that it is now in the political arena and it is challenging the capitalist system just as that system had challenged feudalism in the past. The President said that ... people should have free choice. In some cases minorities seize control in areas associated with us, minorities which do not express the will of the people. Such groups associate themselves with the USSR and act against the interests of the United States. The USSR believes that this is a historical inevitability. This is a matter of concern to us because we do not believe that this is a historical inevitability. Mr. Khrushchev ... wondered whether the United States wanted to build a dam preventing the development of human mind and conscience. To do such a thing is not in man's power. The Spanish Inquisition burned people who disagreed with it but ideas did not burn and eventually came out as victors. Thus if we start struggling against ideas, conflicts and clashes between the two countries will be inevitable. Once an idea is born it cannot be chained or burned. History should be the judge in the argument between ideas.

The President expressed his belief that his and Mr. Khrushchev's obligation to the peoples of the U.S. and the USSR respectively was to have this struggle for ideas, which is part of our times, conducted without affecting the vital security interests of the two countries. . . Mr. Khrushchev said that he hoped that he had misunderstood the President's remarks. ... Did the President want to say that Communism should exist only in those countries that are already Communist and that if Communist ideas should develop the U.S. would be in conflict with the USSR? Such an understanding of the situation is incorrect, and if there really is such an understanding, conflicts will be inevitable. Ideas do not belong to any one nation and they cannot be retracted. ${ }^{31}$

31. U.S. Department of State, Foreign Relations of the United States, 1961-1963, Vol. 5 (Washington, DC: Government Printing Office, 1998), pp. 174-176 (hereinafter referred to as FRUS with appropriate volume and page numbers). For an interesting discussion of this conversation, see Zubok and Pleshakov, Inside the Kremlin's Cold War, pp. 243-248. For the general argument that the international 
For Soviet leaders, then, the concept of status quo made little sense. Radical change in general and the advance of socialism in particular were deemed inevitable. In a foreign policy memorandum adopted by the Soviet Politburo in January 1967, Foreign Minister Andrei Gromyko argued that

the main foreign policy principle of Kennedy and Johnson is to preserve the status quo in the world. .. . However, the American government has set out to prevent Communism from further spreading all over the world, which is, of course, impossible. ... [I] n the present epoch of transition, the question is, in the final analysis, just how the transitions of countries and nations from capitalism to socialism will proceed. ${ }^{32}$

Even in the late Brezhnev period, Soviet leaders believed that the Third World would eventually become socialist and that it was their internationalist responsibility to do what they could to support "progressive" movements.

Despite official American perceptions, in most cases the Soviet Union was merely taking advantage of opportunities in the Third World rather than creating them. The war in Vietnam, the African adventures, and Afghanistan were all responses to the initiatives of local actors. If world politics had been controlled by the superpowers, these disturbances might have been settled relatively easily. Many Soviet officials understood (if only imperfectly) and regretted the damage that these conflicts did to relations with the United States. But they were ambivalent and, despite seeing the problems, also welcomed the weakening of U.S. influence, the additions to the Soviet camp, and the seeming vindication of Communist ideology. As Anatolii Dobrynin put it when describing Soviet activities in Africa in the late 1970s: "Each of these situations of course had its own local peculiarities. But underlying them all was a simple but primitive idea of international solidarity, which meant doing our duty in the anti-imperialist struggle." This imperative was linked to the belief that the status quo must be changed and that the engine of change was not the Soviet Union itself but the forces of history in the form of "the collapse of the old colonial empires and the general weakening of the capitalist system. These were not of our making, declared Mikhail Suslov with Leonid Brezhnev's support, because they were 'historically inevitable."'33

system lacked legitimacy in Soviet eyes, see Robert Legvold, "The Three Russias: Decline, Revolution, and Reconstruction," in Robert Pastor, ed., A Century's Journey: How the Great Powers Shape the World (New York: Basic Books, 2000), pp. 139-190. This is not to imply that American leaders believed that the world could stand still. John Foster Dulles was especially clear on the importance of harnessing the dynamic forces in world politics; see Robert Bowie and Richard Immerman, Waging Peace: How Eisenhower Shaped an Enduring Cold War Strategy (New York: Oxford University Press, 1998).

32. Dobrynin, In Confidence, p. 649.

33. Ibid., pp. 409, 413. It is not surprising that Dobrynin himself, caring more about Soviet-American relations than the spread of Communism, refers to the "ideological bondage" that entrapped Soviet 
Local politics also thwarted the hope for stability and mutual security at the start of the Cold War. Even though a "soft" Soviet sphere of influence in Eastern Europe might have been acceptable to the superpowers, such an arrangement was infeasible. Franklin Roosevelt believed that the way to satisfy legitimate Soviet demands for security without completely abandoning democratic values was to acquiesce in a loose but effective form of Soviet control in Eastern Europe, which would prevent the local countries from adopting policies that would menace the USSR. ${ }^{34}$ Those countries would not be fully autonomous or democratic, but neither would they be ruled with an iron hand from Moscow. What was hoped for-and what might have mitigated much of the Cold War-was something like what later evolved in Finland. ${ }^{35}$ No less a figure than Winston Churchill told the House of Commons in 1945 that he could not "conceive that it was not possible to make a good solution whereby Russia gets the security she is entitled to have, ... and, at the same time, the Polish nation has restored to them that national sovereignty and independence, for which they have never ceased to strive. ${ }^{36}$ Nevertheless, even if such solutions could have been designed, they could not have lasted in a world in which Soviet tolerance for dissent was essentially nonexistent, local populations were deeply hostile to the Soviet Union, and (unlike in Finland) the indigenous elites and political organizations were not strong enough to maintain regimes that could be acceptable to Moscow without being fully under its command.

Other forms of uncontrolled change were also important during the Cold War. Although these phenomena created and exacerbated insecurity, they do not fit well with standard notions of the security dilemma. This was particu-

leaders (p. 268; also see pp. 144-145, 376-377). For a brief but interesting report of Reagan's analysis of Soviet views on this point, see ibid., pp. 525, 562. The role of ideology has received increased attention since the end of the Cold War. See, for example, Gaddis, We Now Know; Melvyn Leffler, The Specter of Communism: The United States and the Origins of the Cold War, 1917-1953 (New York: Hill and Wang, 1994); and Nigel Gould-Davies, "Rethinking the Role of Ideology in International Politics During the Cold War," Journal of Cold War Studies, Vol. 1, No. 1 (Winter 1999), pp. 90-109. For earlier treatments, see Rod Carew-Hunt, "The Importance of Doctrine" and Richard Lowenthal, "The Logic of One-Party Rule," both in Alexander Dallin, ed., Soviet Conduct in World Affairs (New York: Columbia University Press, 1960), pp. 37-46 and 58-74. Also see Zbigniew Brzezinski and Samuel Huntington, Political Power USA/USSR (New York: Viking, 1965), chs. 1-2.

34. Eduard Mark, "American Policy Toward Eastern Europe and the Origins of the Cold War, 19411946: An Alternative Interpretation,” Journal of American History, Vol. 68, No. 2 (September 1981), pp. 313-336; and Warren Kimball, The Juggler: Franklin Roosevelt as Wartime Statesman (Princeton, NJ: Princeton University Press, 1991), ch. 5.

35. In the late $1940 \mathrm{~s}$ and early 1950 s some American officials continued to seek the Finlandization of Eastern Europe; see Ronald Krebs, "Liberation à la Finland: Reexamining Eisenhower Administration Objectives in Eastern Europe," Journal of Strategic Studies, Vol. 20, No. 3 (September 1997), pp. 1-26; Gregory Mitrovich, Undermining the Kremlin: America's Strategy to Subvert the Soviet Bloc, 1947-1956 (Ithaca, NY: Cornell University Press, 2000); and Bowie and Immerman, Waging Peace.

36. Quoted in Warren Kimball, Forged in War: Roosevelt, Churchill, and the Second World War (New York: Morrow, 1997), p. 306. 
larly evident in the competition for influence over Germany, which was central to the Soviet-American conflict. Both superpowers wanted arrangements that would help them keep events from eluding their control. Scholars have been slow to understand this, and almost all discussions of the division of Germany equate responsibility with blame: Whichever country sought to divide Germany is said to have started the Cold War. This perspective overlooks the role of the division in facilitating superpower cooperation by giving each a stake in the status quo. It also ignores the difficulties that would have been posed by a united and neutral Germany that would have been courted by both superpowers. Without firm ties to either side, Germany undoubtedly would have sought nuclear weapons and the freedom to lean in one direction or another, which would have been a source of great apprehension to the "losing" side. Indeed, this logic is what ultimately convinced Gorbachev that if Germany was to be reunited, the Soviet Union would be more secure with Germany tied to the North Atlantic Treaty Organization (NATO) than if it were left on its own.

\section{American Goals and Beliefs}

Unlike the Soviet Union, the United States wanted to freeze the status quo at the end of World War II. At any point in the Cold War (with the significant exception of its final years when victory was in sight), U.S. officials would have been happy to sacrifice the possibility of further gains in return for a high degree of security. Given the advantageous position of the United States, this is not surprising. Even so, American leaders did not believe that mutual security was a realistic goal. At the start of the Cold War, the image of the Soviet Union as unremittingly hostile (if cautious), combined with instability in Western Europe and the expected dangers of prolonged competition with the USSR, spurred efforts to decrease Soviet power. This objective was pursued through covert action and psychological warfare, which, though defensively motivated and largely ineffective, were clearly offensive in their impact. ${ }^{37}$

Later, as Western Europe became stabilized and the United States developed greater faith in nuclear deterrence and saw that the domestic burdens of the Cold War were manageable, coexistence seemed more feasible. ${ }^{38}$ Even

\section{Mitrovich, Undermining the Kremlin.}

38. Less well known than the fears of bankruptcy were the concerns about becoming a garrison state. See Michael J. Hogan, A Cross of Iron: Harry S. Truman and the Origins of the National Security State (New York: Cambridge University Press, 1998); and Aaron Friedberg, In The Shadow of the Garrison State: America's Anti-Statism and Its Cold War Grand Strategy (Princeton, NJ: Princeton University Press, 2000). 
then, however, most American officials believed that although the USSR might not pose an immediate military threat to American vital interests, Soviet leaders were still seeking to neutralize Western Europe and expand their influence throughout the world. These changes in the status quo would have been unacceptable to American leaders because they both diminished American values and were seen as likely to produce further reverses. Short of a Soviet surrender, then, cooperation could not go far, and it is not surprising that Nixon and Kissinger later claimed that détente had been a way to buy time until the American political system was willing to tolerate renewed competition. ${ }^{39}$ Indeed, successive U.S. administrations never lost sight of the objectives laid out in the first official statement of U.S. objectives in the Cold War:

a. To reduce the power and influence of the USSR to limits which no longer constitute a threat to the peace, national independence and stability of the world's family of nations.

b. To bring about a basic change in the conduct of international relations by the government in power in Russia, to conform with the purposes and principles set forth in the UN charter. ${ }^{40}$

American leaders feared that the existence of a strong and healthy Soviet Union (and perhaps even any Soviet Union at all) created a serious threat to Western security. American motives were essentially defensive: to "counter the threats to our national security and well-being posed by the USSR." ${ }^{41}$ But even if the United States did not want to run major risks to roll back Soviet influence, U.S. efforts to exploit opportunities that arose were indistinguishable in their effect from expansionism, which means that the situation was a deep security dilemma.

In many conflicts in the Third World the chance of direct military confrontation was slight, thus reducing common interest and feeding each side's belief that gains for the other were losses for itself. Soviet leaders were confident that revolutions would move Third World countries into their

39. Indeed, although Nixon and Kissinger defended détente on quite different grounds at the time, they came to portray it in their later writings in terms not unlike the critique developed by Garthoff in Détente and Confrontation. For Dobrynin's analysis of Brezhnev's views of the limits of détente, see In Confidence, pp. 376-377.

40. NSC 20/4, in FRUS, 1948, Vol. 1, Part 2, pp. 667-668. For the argument that Eisenhower's policy was designed to meet these objectives and that many of his diplomatic initiatives were aimed not at reasonable settlements but at convincing Western publics that American intentions were peaceful, see Kenneth Osgood, "Form before Substance: Eisenhower's Commitment to Psychological Warfare and Negotiations with the Enemy," Diplomatic History, Vol. 24, No. 3 (Summer 2000), pp. 405-433. Also see Matthew Evangelista, "Cooperation Theory and Disarmament Negotiations in the 1950s," World Politics, Vol. 42, No. 4 (July 1990), pp. 502-528.

41. NSC 20/4, in FRUS, 1948, Vol. 1, Part 2, pp. 667-668. 
camp; Nixon and Kissinger proudly claim in their memoirs that their endorsement of détente was coupled with efforts to minimize Soviet influence in the Third World. As Kissinger put it with respect to the most important area of conflict: "A principal purpose of our Mideast policy was to reduce the role and influence of the Soviet Union, just as the Soviets sought to reduce ours." ${ }^{\text {"42 }}$ Even if the United States primarily sought security, the unintended effect was to preclude mutually acceptable arrangements.

From the perspective of the dominant theory of international politics, the American attitude is puzzling. According to many political scientists, a bipolar system, especially one in which both sides possess secure second-strike capabilities, should readily yield mutual security. ${ }^{43}$ It is easy for each side to protect itself through deterrence without threatening the other's vital interests. The United States, in this view, should not have felt menaced by Soviet gains in the Third World and should not have assumed that American security required the contraction of Soviet power. Persuasive as this theory was to some scholars, it never convinced the superpowers' leaders. Two linked beliefs, which were especially strong on the American side, ensured that each side's policies were competitive and even offensive. The first was deterrence theory's stress on the importance of resolve. Because all-out war could not be rational, it was both crucial and difficult to make plausible the threat to trigger it. Extraordinary measures were necessary, such as behaving unpredictably and committing oneself to defend exposed positions like West Berlin. In principle, each side might evince a high resolve to defend what it had without simultaneously seeking to infringe on the other's interests, but in practice this was very difficult.

The second core belief can be broadly described as the domino theory, which was partly derived from the importance of resolve: If the United States did not defend all countries from Communism, others would infer that American inaction was a stable characteristic and would be repeated around the globe. Adversaries would then be encouraged to press harder and allies would lose faith, which would make attacks against American interests more likely and their defense more difficult. This implied that all challenges had to be met and that every "free" country had to be protected, thereby ensuring

42. Henry Kissinger, Years of Upheaval (Boston: Little, Brown, 1982), p. 600. Also see Kissinger, Years of Renewal (New York: Simon and Schuster, 1999), pp. 580-581. Elsewhere Kissinger says that he would have accepted a Soviet role if the USSR had been willing to "separate itself from its radical clients to the same extent that Moscow was asking us to distinguish our position from Israel's" (Years of Renewal, p. 353). Although such a stance might have helped the peace process, it would also have increased Soviet influence and therefore, I suspect, would not have been welcomed.

43. Most notably, Waltz, Theory of International Politics. Also see Robert Jervis, The Meaning of the Nuclear Revolution (Ithaca: Cornell University Press, 1989). 
continuing conflict in a changing world and leaving little room for cooperation with the Soviet Union. ${ }^{44}$

\section{Elements of the Security Dilemma in the Cold War}

None of this means that the Cold War lacked important elements of a classic security dilemma that could have yielded a better outcome for both sides. The Cold War frequently heightened tensions, fed misperceptions, and complicated attempts to resolve disputes. Although the outlines of a mutually acceptable arrangement in Europe had been established by the early 1950s, it took almost a quarter of a century before that arrangement was formalized in the Quadripartite Agreements and the Helsinki Accords. The intervening delay and conflict are partly attributable to the lack of indigenous support for the Soviet Union in Eastern Europe and to Dwight Eisenhower's desire to compensate for the prospective withdrawal of American troops by giving Germany access to nuclear weapons, an outcome that was unacceptable to the Soviet Union. ${ }^{45}$ Nevertheless, there was a status quo that was tolerable to both sides and that might have been stabilized sooner and with less strife if each side had understood the other's fears and interests. In that case, both sides would have settled for security, a goal that was not entirely out of reach.

The arms competition may also have constituted a security dilemma, at least after the Soviet Union achieved a second-strike capability in the mid1960s. Security dilemma analysis would be misleading if we found that either side was willing to pay a high price to gain superiority in order to coerce the other into changing the status quo. Although such preferences were held by some U.S. military commanders even after U.S. political leaders had reconciled themselves to the existence of a secure Soviet retaliatory capability, most civilians who sought superiority did so for self-protection: that is, to provide insurance in case of war, to bolster deterrence, and to mollify domestic critics.

44. Ideology played a role in U.S. leaders' perceptions that all radical movements were Communist. See Louis Hartz, The Liberal Tradition in America (New York: Harcourt Brace, 1955). Critics of American foreign policy not only ridiculed the domino theory, but saw it as so implausible that they had to assume it was a cover for the desire to control and exploit the Third World. This argument, however, fails to explain the disproportion between American efforts to prevent dominoes from falling and the intrinsic value of the countries at stake, particularly Vietnam. To the extent that critics argue that efforts like the Vietnam war were really aimed at maintaining America's general position in the world, their critique becomes analytically indistinct from that of the policy's defenders in implicitly endorsing the domino theory.

45. Trachtenberg, A Constructed Peace. Ironically, although the withdrawal of U.S. troops was an ostensible goal of Soviet policy, it would have presented dangers as well as opportunities, as Leonid Brezhnev acknowledged when he offered talks on mutual force reductions and thereby undercut the pending Mansfield Amendment calling for the unilateral removal of many American forces. 
But even if the motives were defensive, the pursuit of superiority was itself bound to perpetuate a deep security dilemma. Mutual security came within reach only when leaders on both sides became willing to give up the hope for superiority in return for arrangements that precluded the other side from achieving it and that lowered tensions and reduced spending (at least in principle).

Although each side tended to believe that the other was striving for superiority in order to increase its political leverage, the evidence suggests that after the mid-1960s leaders on both sides did not seek superiority for this reason and were not influenced by the details of the nuclear balance during crises. Both governments were driven by nightmares of inferiority (reinforced by the political influence of the military), not by hopes for gain. Even though Soviet leaders never accepted the more theological aspects of Western arms control theory, they soon realized that a nuclear war would be a disaster beyond all comprehension. Hence, they were eventually willing to constrain strategic weapons, and they did not seek political advantage through the ability to conduct limited nuclear strikes. The process of acquiring additional arms generated conflict rather than merely reflecting it, and greater empathy and political ingenuity on both sides could have moved them toward a common interest.

This was even more true for conventional arms in Europe. Although Soviet leaders needed a large army to ensure control over their East European clients, they decreased their security by deploying not only an excessive force, but one configured to take the offensive. There is no reason to believe that Soviet leaders ever seriously contemplated launching an unprovoked, all-out attack, at least not after 1950; but when Western leaders looked at Soviet forces and doctrine, they had to assume the worst. The buildup of Soviet conventional forces pushed the United States to develop larger strategic forces and more diverse nuclear options that it could implement in the event of a Soviet attack in Europe, a posture that was bound to threaten the USSR. The West could have been reassured, and greater cooperation could have been attained, if the Soviet Union had adopted a defensive stance, as Gorbachev realized. Adopting such a posture earlier would have served Soviet interests. The offensive policy was maintained only because few civilian leaders knew much about it and because Brezhnev and his immediate successors shied away from challenging the military.

Much of Moscow's general diplomacy, and not just its military policy, contributed to the country's self-encirclement. It is hard to believe that the capitalist world would have united had Stalin not acted on the assumption that capitalist countries would be in conflict with one another. Time and 
again the Soviet Union made enemies of potential friends (or at least potential neutrals), failed to divide Western Europe from the United States, and committed provocations that not only alarmed American leaders but allowed them to muster domestic support for anti-Soviet policies. It is worth noting, however, that when determining whether Soviet actions were part of a true security dilemma, we have to consider whether those actions were purely defensive. A defensive intent is far from clear. Although Soviet leaders clearly did not want Western resistance to grow, it is unlikely that they would have been willing to abandon their efforts in return for a guarantee of the status quo.

Complexity and ambivalence also characterize the broader question of whether the superpowers were driven primarily by fear rather than the hope for gain, as security dilemma analysis expects. Fear certainly permeated the Cold War; indeed it was built into our sense of it. But fear is not unique to the security dilemma, and several of the roles it played do not fit well with that concept. Although decision makers dreaded war, especially nuclear war, and realized that it could occur even if no one intended it, this fear not only increased international tension (as the security dilemma implies), but also produced restraint. ${ }^{46}$ Leaders on both sides were especially fearful during crises, but they did not succumb to a self-fulfilling prophecy of war-the ultimate form of the security dilemma. Rather, each side refrained from pressing the other as hard as it could have. ${ }^{47}$ This was most notable during the Cuban missile crisis. In retrospect, it seems that Kennedy did not have to make his secret promise to withdraw Jupiter missiles from Turkey, and that Khrushchev probably could have extracted more-such as a public American pledge to withdraw the Jupiters - in return for his concessions. Neither side, however, chose to press its luck. The costs of failing to agree were too overwhelming.

How much was either side concerned about the danger of aggression, which is the heart of the security dilemma? Although the United States went to great lengths to ensure its second-strike capability, most officials believed that an all-out attack, and even a conventional assault on Western Europe, was quite easy to deter. Despite the repeated invocation of the Munich analogy, no Soviet leader was seen as a Hitler willing to gamble his life and regime

46. During conversations with Kennedy in Vienna, Khrushchev denied the possibility of war by miscalculation. See FRUS, 1961-1963, Vol. 5, pp. 173-177. But his behavior and letters during the $\mathrm{Cu}-$ ban missile crisis showed his sensitivity to the danger. Zubok and Pleshakov argue that Khrushchev's earlier denials grew out of his belief that Kennedy was seeking to negate Soviet threats. See Inside the Kremlin's Cold War, pp. 245-246.

47. The classic analysis of the danger is Thomas C. Schelling, The Strategy of Conflict (Cambridge, MA: Harvard University Press, 1960), ch. 6, which underpinned the American theory and, to a lesser extent, practice of arms control. For a discussion of why an awareness of potential dangers can lead to behavior that reduces them, an effect that may have been at work here, see Jervis, System Effects, ch. 6. 
on a cosmic throw of the dice. Rather, the fears were more vague and less direct, involving instabilities of various kinds. Nevertheless, it was still fear, not the hope for gains, that was driving U.S. policy. Or, to put it more precisely, it was fear that motivated the United States to seek gains.

Soviet leaders feared the West in the sense of worrying that it would block their moves, but this is quite different from what the security dilemma has in mind. Of course some Soviet officials may have been concerned that the West would take the offensive. The capitalists were seen as ruthless and aggressive, and certain measures, including the consolidation of Soviet control over Eastern Europe, were motivated in part by the perceived threat to what the Soviet Army had achieved. Most strikingly, Mao Zedong's intervention in Korea stemmed from his belief that U.S. troops north of the 38th parallel would menace China, and the Soviet Union's invasion of Afghanistan was intended to salvage a faltering client, not to prepare for new adventures. But it is usually hard to gauge the extent, occasions, and causes of Soviet fears of the West, in part because the documents do not readily yield such information. Official analyses of the Western threat often are vague and subject to multiple interpretations. Although Dobrynin claims that by the early 1950s "Stalin saw U.S. plans and actions as preparations for an all-out war of unprovoked aggression against the Soviet Union," this fear produced restraint more than it did belligerence and escalating spirals. ${ }^{48}$ If a full-fledged security dilemma had existed, Soviet leaders would have responded with arms and hostility to prevent the West from exerting pressure and disrupting the status quo.

\section{Conclusion}

Although the Cold War contained elements of the security dilemma and included episodes in which tensions and arms increased as each side defensively reacted to the other, the root of the conflict at best was a clash of social systems. Mutual security in these circumstances was a goal that could not be attained. For the Soviet Union, mutual security was not a goal at all if "security" is equated with maintaining the status quo. The basic Soviet view of politics

48. Dobrynin, In Confidence, p. 26. Also see Nikita Khrushchev, Khrushchev Remembers: The Glasnost Tapes, ed. and trans. by Jerrold Schecter and Vyacheslav Luchkov (Boston: Little, Brown, 1990), p. 147; Zubok and Pleshakov, Inside the Kremlin's Cold War, pp. 50-51, 62, 72; and Leffler, The Specter of Communism, ch. 3. It is often said that the Marshal Plan greatly increased Stalin's fear. Ulam, Expansion and Coexistence, pp. 435-437; Marshall Shulman, Stalin's Foreign Policy Reappraised (Cambridge, MA: Harvard University Press, 1963), pp. 13-17; Taubman, Stalin's American Policy, ch 7; and Scott Parrish and Mikhail Narinsky, "New Evidence of the Soviet rejection of the Marshall Plan, 1947: Two Reports," Working Paper No. 9, Cold War International History Project, Washington, DC, March 1994. This is not the view that Stalin expresses in one document, however. See Murray, "Stalin, the Cold War, and the Division of China," p. 22. 
(both domestic and foreign) as class conflict meant that "socialism in one country" could never be sufficient. This is not to say that Soviet leaders were intent on conquering the West by force of arms; the Soviet archives have yet to reveal any serious plans for unprovoked aggression against Western Europe, not to mention a first strike against the United States. Furthermore, by the early 1950s Stalin's hopes that local Communist parties would gain power in Western Europe through a combination of subversion and Soviet pressure had faded. What remained was the basic premise that history was moving toward Communism and that the Soviet Union had the responsibility to aid its progress. This did not mean that Soviet leaders were willing to risk what they had already achieved in order to get more. But they did want, expect, and seek more.

Although analogous desires were present in the United States, they were instrumental rather than intrinsic. The United States had enough of what it valued, and it would have gladly frozen the status quo if that had been possible. But because it was not possible, the United States often pursued offensive tactics. U.S. officials assumed that the competition would continue as long as there was a Communist Soviet Union, and they concluded that the reduction of Soviet influence throughout the world was the only realistic objective. Every American president except Jimmy Carter in the first years of his term agreed with a 1952 Policy Planning Staff paper that declared:

we believe that ... [containment] is inadequate and also unrealistic. We do not believe that the situation can remain indefinitely static. One side will gain and the other will decline as a factor in world affairs. It must be our objective to be the one which gains. ${ }^{49}$

George Kennan argued that "many people in the Western governments came to hate the Soviet leaders for what they did. The Communists, on the other hand, hated the Western governments for what they were, regardless of what they did." ${ }^{50}$ The first part of this claim needs modification. Despite American military strength, U.S. officials did not believe in the viability of "capitalism in one country." As Melvyn Leffler has stressed, a sense of vulnerability was a common thread in the American opposition to both Nazi Germany and the Soviet Union. What Walter Lippmann said in 1940 was believed throughout the Cold War: "The fact is that a free economy, such as Americans have known, cannot survive in a world that is elsewhere under the

49. "Basic Issues Raised by Draft NSC 'Reappraisal of U.S. Objectives and Strategy for National Security,"' Policy Planning Staff draft, in FRUS, 1952-1954, Vol. 2, p. 64. Carter's ability to cooperate with the USSR was limited not only by Soviet behavior and by divisions within his administration, but also by his commitment to human rights within the Soviet Union.

50. George Kennan, Russia and the West Under Lenin and Stalin (New York: Mentor, 1962), p. 181. 
regime of military socialism." ${ }^{51}$ Although neither American interests nor American ideology ruled out indefinite coexistence with a USSR confined to its own sphere, the belief that the Soviet Union was inherently expansionistic rendered such an outcome infeasible. This was especially true because American leaders believed that the instability of world politics precluded a purely defensive posture. The nuclear stalemate meant that demonstrations of resolve were crucial, and the only way to underscore U.S. resolve was by prevailing in crises. In the Third World, Soviet gains were seen as likely to trigger domino effects, making cooperation there problematic.

Given the basic beliefs and conceptions of self-interest on each side, there is little reason to believe that even the best diplomacy could have brought an end to the Cold War. Soviet documents that are now available do not indicate a willingness to reciprocate conceivable American peaceful initiatives, though it is worth noting that even complete records might not be sufficient to answer counterfactuals of this sort. The American archives and the record of American behavior also provide little basis for assuming that anything short of Moscow's acceptance of the status quo throughout the world would have led to good relations. It is not a coincidence that the Cold War ended only after fundamental changes occurred in the Soviet Union, including Gorbachev's abandonment of the central idea of international politics as a manifestation of the class struggle. Although periodic détentes were possible in the absence of such changes, a true end to the Cold War was not.

51. Quoted in Leffler, Specter of Communism, p. 31. 
Copyright of Journal of Cold War Studies is the property of MIT Press and its content may not be copied or emailed to multiple sites or posted to a listserv without the copyright holder's express written permission. However, users may print, download, or email articles for individual use. 